\title{
TRANSFER OF EMBROIDERY ELEMENTS FROM BULGARIAN NATIONAL FOLK COSTUME TO THE CONTEMPORARY FASHION
}

\author{
Zlatin Zlatev ${ }^{1}$, Petya Boneva ${ }^{2}$, Vanya Stoykova ${ }^{1}$, EISayed A. EINashar ${ }^{3}$ \\ ${ }^{1}$ Faculty of Technics and Technologies, Trakia University, Bulgaria, \\ 38 Graf Ignatiev str., 8602 Yambol, Bulgaria, e-mail: zlatin.zlatev@trakia-uni.bg \\ ${ }^{2}$ University of Ruse, Agrarian and Industrial Faculty, Department of Industrial Design, \\ 8 Studentska str., POB 7017, Ruse, Bulgaria, e-mail: pboneva@uni-ruse.bg \\ ${ }^{3}$ Faculty of Specific Education, Kafrelsheikh University, Egypt, \\ El-Geish Street, 33516 Kafrelsheikh City, Egypt, e-mail: Smartex@kfs.edu.eg
}

\begin{abstract}
The goal of this research is the analysis of two dimensional images of embroidery elements and the development of techniques for shape and color segmentation in the automation of embroidery designs. A document camera is used as a tool for obtaining of color digital images of embroidery elements from Bulgarian national folk costume. Also are devised some techniques for color restoration of elements and their skeletons. Files for embroidery machines are described and obtained then the results are checked with commercial software. A website is created for presentation of the results of this work.
\end{abstract}

Keywords: Image analysis, Document camera, Embroidery, Bulgarian national folk costume.

\section{INTRODUCTION}

The rapid advancement of internet and mobile internet, e-commerce has facilitated international trade and daily shopping. Appealed by the potential large market, many companies have already got engaged in the development of new products aimed not only to the market in one country or in the localization of the old products in the market [13]. In order to achieve this ambition, one of the necessary steps is to localize the external design of the product [22]. This requires research into methods for rapid prototyping and flexibility to produce products that line with the individual needs and desires of the individual consumer. The modern manufacturing seeks optimum between small orders and relatively low production costs.

To ensure success in the market of clothes, the designer can build and apply activities with varied creative approaches $[2,6,7]$. As an object of design of clothes, the embroideries are instrument through which they become attractive to consumers. The embroidery elements of Bulgarian national costume, their shapes, colors and proportions between them are a basis for creation of modern clothing.

The evolution of technology in the textile industry reached the design of embroidery patterns for machine embroidery. In order to create quality designs the shapes to be embroidered need to be segmented into regions that define different parts [8].

With the development of computer aided techniques currently, the vectorization becomes a focus of researches in many fields such as apparel industry, mass personalization, which makes graphics inputs from human computer interaction technique to computer input automatically. In this way, vectorization can not only save memory but also improve the intelligent level and the efficiency of graphics inputs. Thus, the vectorization becomes one method to solve the prevalence and application of the CAD technique and has an important theoretical and practical significance [14, 15, 21]. Now the computer embroidery systems [1,

IRTITE Vol. 4, No. 2, 2016 ISSN 1314-8788 (print), ISSN 1314-8796 (online), doi: 10.15547/artte.2016.02.003 
23] are prevalent in the world. Its strongpoint is the precision of the input. But the cost is very high and the efficiency is low.

The goal of this research is the analysis of two dimensional images of embroidery elements and the development of techniques for shape and color segmentation in the automation of embroidery designs. For this purpose, also are devised some techniques for color restoration of elements and skeletization.

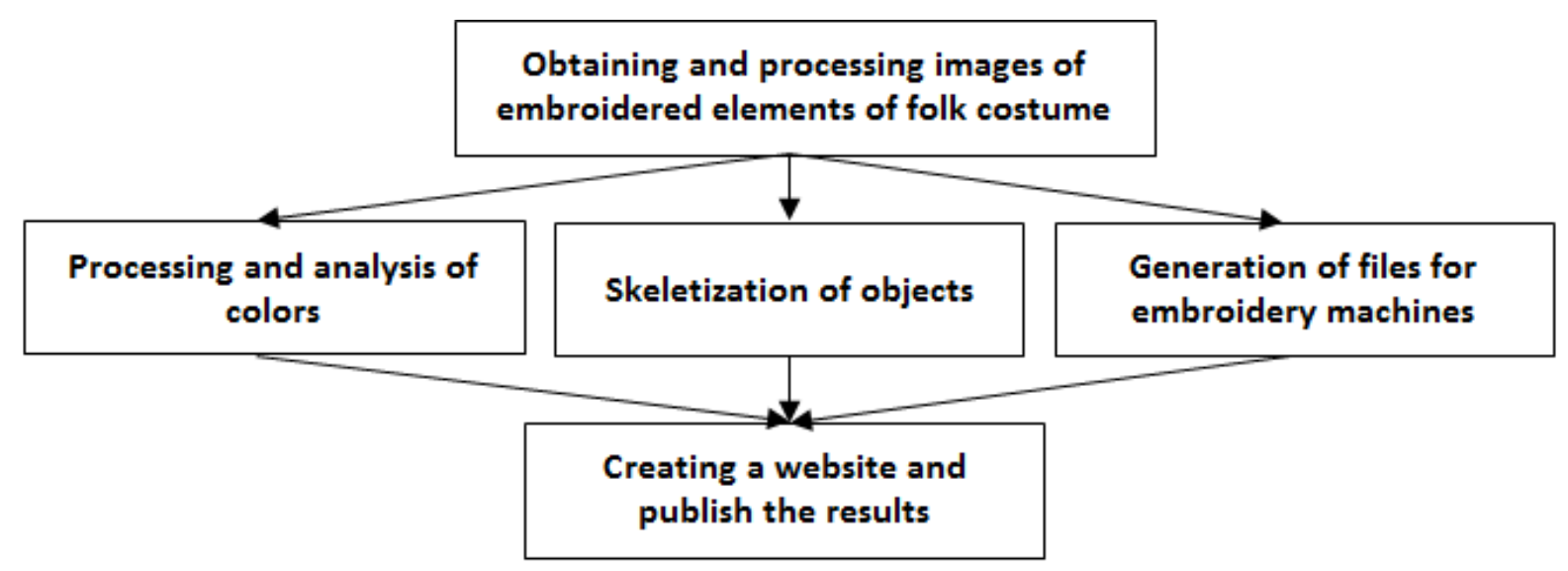

Figure 1. Structure of the paper

The rest of this paper is organized as presented in Figure 1. Section 2 reviews the related work. Section 3 describes the material and methods that are used. In Section 4 are present results of the study. Approaches used for extraction, analysis and restorations of colors of embroidery elements. Presented is research on morphological characteristics of embroidery elements. Files for embroidery machines are described and obtained then the results are checked with commercial software. A website is described that is created for presentation of the results of this work. Finally, some concluding remarks are provided in section 5 .

\section{RELATED WORK}

In modern stage of development of science, after 2000s, is seen directing the research related to analysis of fabrics, embroidery and textile production to the Asian region. This is related to the shift of textile production from Europe and America to Asian countries [22]. The main research in this area are related to the automation of processes, use of systems for pattern recognition to speed up the design and reducing the cost of the final product.

A novel method for inputting embroidery images is presented in [14]. The method can convert BMP image format to DXF graphics format automatically. Firstly, the embroidery image is captured by a scanner; secondly, the image is converted to a graphics by means of image processing and multinominal fitting algorithm; finally, a special graphics file is created to the DXF graphics format. Test results using this method showed that the algorithm achieved a good quality and improved the efficiency of inputs greatly.

Kuo et al. $[9,10,11]$ state that currently there is small numbers of literature on automatic image recognition and classification of embroidery fabrics. In today's embroidery industry, front-end pattern-making still relies greatly on labor, using pattern-making software to carefully depict patterns and images in different colors and regions. Hence, an image analysis system that can recognize colors, regions and patterns automatically is a critical technique of improving the competitiveness of the embroidery industry. In this series of papers, the mean filtering method, central-weighted median filtering method and

IRTITE Vol. 4, No. 2, 2016 ISSN 1314-8788 (print), ISSN 1314-8796 (online), doi: 10.15547/artte.2016.02.003 


\section{ARTTIE $Y$}

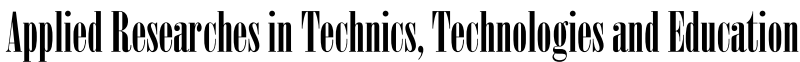

Journal of the Faculty of Technics and Technologies, Trakia University https://sites.google.com/a/trakia-uni.bg/artte/

morphological operation were employed to filter out the light variation on the embroidery fabric surface structure, and a genetic algorithm was applied to distinguish images of repeat pattern embroidery from that of nonrepeat pattern embroidery. By extracting the color $a^{*}$ component and $b^{*}$ component of the machine embroidery image in CIE L*a* $b^{*}$ color system, is used the Gustafson-Kessel clustering algorithm for color separation. The authors made series of study proposed the automatic machine embroidery image color analysis system as an extension of the previous proposed machine embroidery color separation system and repetitive pattern search system. This paper integrated the machine embroidery image color analysis system to achieve system automation. Their study implemented the chromatography of the color separation results, and used the cluster validity indices to prove that the application of Gustafson-Kessel clustering algorithm in the machine embroidery image color separation system has better results than K-means, K-medoid, fuzzy C-means (FCM), and self-organizing map (SOM) clustering algorithm. The results meet the classifications as the authors expected by human eyes.

Shih et al. [20] propose an automated analysis system for Tatami embroidery fabric images that automates color analysis, pattern shape analysis and texture analysis. Firstly, the RGB (red, green and blue) image of embroidery fabric is obtained by a color scanner. In color analysis, the wavelet transforms and median filter are used for RGB image preprocessing, and then the Fuzzy C-Means (FCM) clustering method is used for the binary region splitting method, the color features of statistical values of colors and number of colors can be obtained. In the pattern shape analysis, the individual pattern components are segmented by the separated colors, and the shape features of pattern components are obtained by moment invariants. Their experimental results show that this method can implement Tatami embroidery fabric color, shape and texture analyses automatically.

Zheng [23] proposes a novel method combining the characteristics of structure and region information is proposed for automatic segmentation of the color region for different kinds of fabrics. For improving image quality for computer analysis, the structure-texture decomposition processing has been used to extract the main structure from the fabric image, where the fine structure details of fabric yarn patterns have been removed. By using the CIELab color system, the color structure image is then segmented by a fuzzy region-based segmentation model that can be solved efficiently through a fast numerical scheme. The experimental results show that the main disadvantage and difficulty of using color clusteringbased methods and commonly used image segmentation methods for fabric color separation is overcome by the proposed method. The proposed method has high accuracy and the computation time is very reasonable. It can be applied to extract fabric color regions for different fabric structures, such as woven, knitted and embroidery structures.

In 2016 Kuo et al. present new results [12] of their series of study and noted that in Embroidered textile is a highly valued artwork. Three-dimensional patterns can be created by variable stitches and the material characteristics of embroidery thread. The authors state that at present, computer plate-making is widely used in embroidery operation, allowing factories to mass-produce efficiently, but in the quality control stage, manpower is needed for visual inspections. The authors noted that there is no specific standard for embroidered textile defects. In order to increase efficiency of human resources, elucidate the defects on embroidery, and achieve automated defect classification, they proposed methods on the recognition and classification of embroidered textile defects. After interviewing producers of embroidered textiles and manufacturers of computer embroidery machines, they identified four types of defect in embroidery textile patterns: foundation yarn floating knit, stitch missing, joint defect, and misregistration for defect recognition. The back-propagation neural network (BPNN) and characteristic procedure classification were used for defect classification. The embroidered textile pattern recognition and classification methods

IRTITE Vol. 4, No. 2, 2016 ISSN 1314-8788 (print), ISSN 1314-8796 (online), doi: 10.15547/artte.2016.02.003 


\section{ARTTIE $Y$}

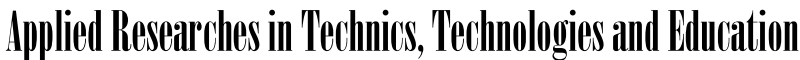

Journal of the Faculty of Technics and Technologies, Trakia University https://sites.google.com/a/trakia-uni.bg/artte/

proposed by this study are expected to provide an automated inspection procedure for the embroidery textile industry.

Mo et al. [16] noted that fabric prints may contain intricate and nesting color patterns. The authors present a self-organizing-map (SOM) based clustering algorithm used to automatically classify colors on printed fabrics and to accurately partition the regions of different colors for color measurement. Unlike many other clustering algorithms, this algorithm does not need to pre-define the number of clusters and can automatically select a distance threshold to partition the U-matrix map. The experimental results show that the intricated color patterns can be precisely separated into individual regions representing different colors.

The analysis of recently published studies in identification and determination of the embroidery in textile products shows that the use of image recognition systems is important priority direction for the automatic determination of their specific characteristics. Explain that the systems for image recognition in the most natural way to interpret this specific expert activities. Optical methods are leading to obtain initial information about the quality of textiles, the main advantages that are distinguished are: non-destructive testing, easy technical realization, high performance, large informative, selectivity, good efficiency, sensitivity, technological compatibility and the remote control. As major trends are emerging use of video cameras to detect external defects and use of hyper-spectral vision systems in the diagnosis of internal defects of embroidered textile products.

In the research relating to the recognition of embroidered elements and automation of processes for manufacturing such products are used complex computational procedures and expensive equipment and should be sought simpler procedures and more common technical devices having the similar opportunities for image processing. Such tool is a document camera, which can be used both for learning and research [4].

\section{MATERIAL AND METHODS}

To realize the objective of this work was used typical of Southeastern Thrace folk costume. It is sukman female costume consisting of a shirt, dress, skirt and girdle as decoration with characteristic embroidered decoration is most noticeable on the skirt and neckline of the sukman.

In Figure 2 is presented in general form the used folk costume with nomenclature referred to embroidered items. This nomenclature is used in the name of the files with raster, vector and metadata for the elements. Presented are a part of the digitized embroidered items from the used folk costume.

The embroidered elements of folk costume are captured with a digital document camera (DC) connected to a personal computer. The choice of technical device can be justified in that the document camera has a number of options for visualization of text materials (incl. Represented in the QR code), static and dynamic 3D objects in enlarged audience, including extra zoom, conducting experiments, joint video sessions through the appropriate application systems for e-learning, with the possibility of recording images, audio and video, and more.

The review of the literature [4] and the discussed good practices [3, 5], prove that high-end DC can be used for various research - to measure the color, object recognition, determination of size. The last and the aforementioned possibilities of DC makes them essential tool for training in modern of interactive classrooms, auditoriums and laboratories of universities in Bulgaria.

IRTTIE Vol. 4, No. 2, 2016 ISSN 1314-8788 (print), ISSN 1314-8796 (online), doi: 10.15547/artte.2016.02.003 


\section{IRTTL $\vee$}

Ipplied Resseirthes in Technics, Technologies and Bductition Journal of the Faculty of Technics and Technologies, Trakia University https://sites.google.com/a/trakia-uni.bg/artte/

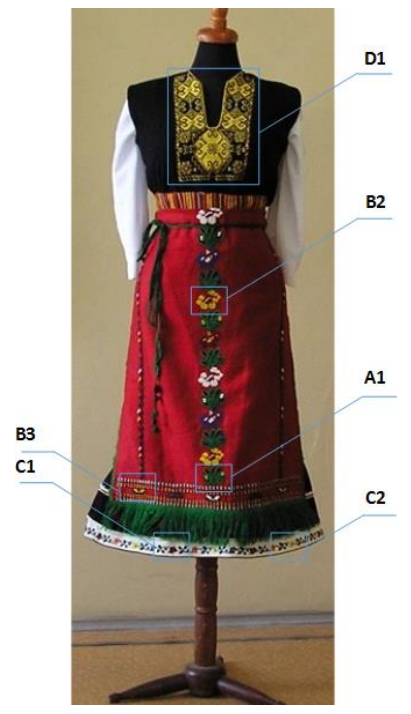

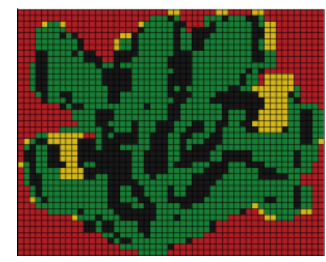

a) element $\mathrm{A} 1$

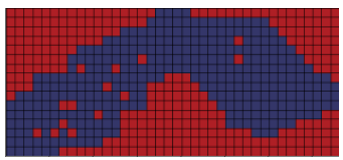

d) element B5

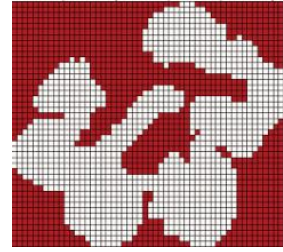

b) element B2

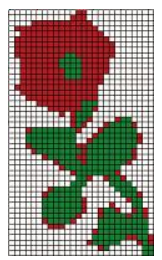

e) element $\mathrm{C} 1$

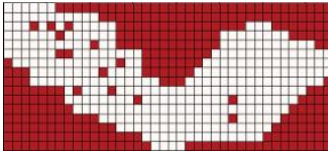

c) element B3

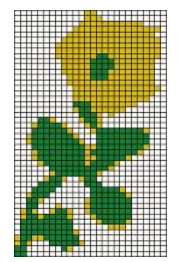

f) element $\mathrm{C} 2$

Figure 2. Digitized embroidered elements of folk costume

In previous studies it has been proposed the application of high-end DC in some atypical, non-academic activities is proposed and justified, taking into account their high parameters in terms of resolution and quality of captured images, high-speed when creating graphics and audio-video files and opportunities for recognition of bar and QR code [4, 25].

Mentioned advantages of the document cameras make them suitable tool to capturing color digital images in order to detect embroidered elements of the Bulgarian national costume.

In Figure 3 is represented the used in the study document camera Epson DC-11. The camera uses a sensor $1 / 4$ CMOS, $5 \mathrm{MP}$, has a feature AutoZoom, internal memory and SD card slot. The connection to a personal computer is via USB interface.

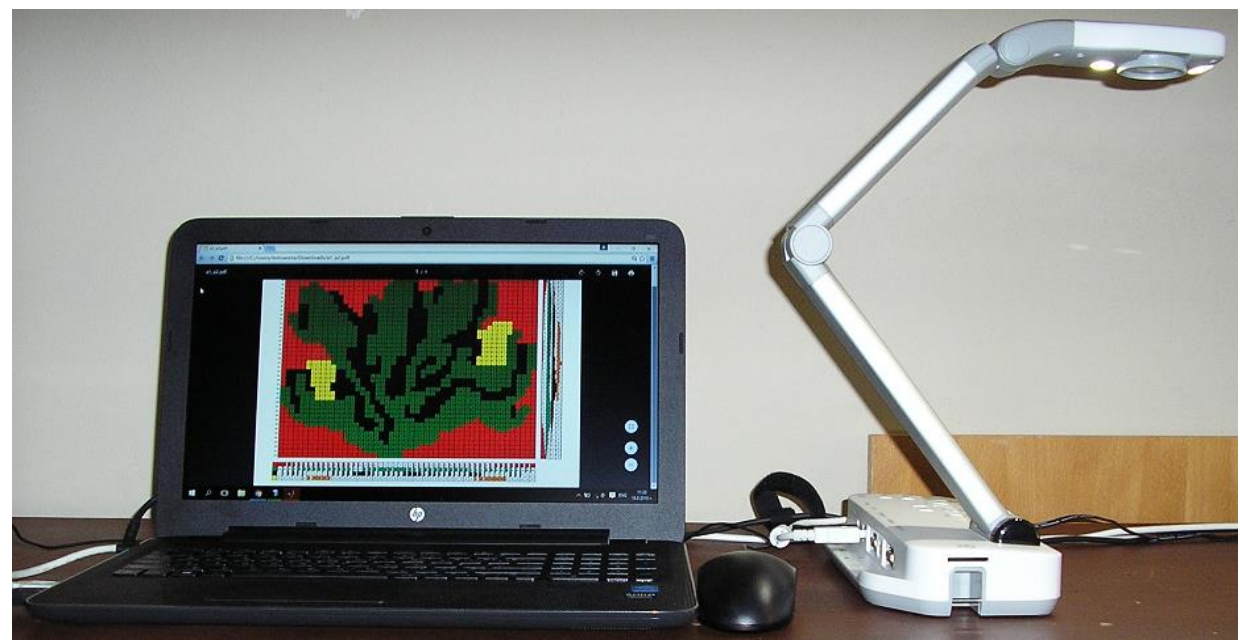

Figure 3. Document camera Epson DC-11 (ELPDC11) 


\section{ARTTL $Y$}

Ipplied Resseirthes in Technics, Technologies and Bductition

Journal of the Faculty of Technics and Technologies, Trakia University https://sites.google.com/a/trakia-uni.bg/artte/

The measurement of color embroidered elements of folk costume is realized with a colorimeter (Figure 4), developed at the Department of "Electronics, Electrical Engineering and Automation" of faculty "Technics and Technologies" - Yambol, Bulgaria. The measuring instrument is built with color sensor TCS34725 and single board micro controller Itead Leonardo.

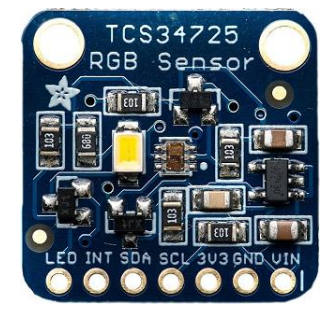

a) color sensor

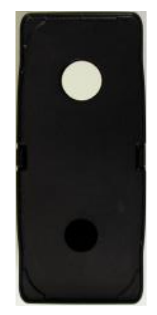

b) color reference

Figure 4. Colorimeter used in the study

To set the color was used reference Lovibond with serial number 12064, produced 2006. Reference consists of black and white a mark with values specified by the manufacturer of the color components from Lab color model. It is also indicated spectral range and the values of the reflectance that can be used to adjust devices for measurement of color. This range is $390-710 \mathrm{~nm}$ with step $10 \mathrm{~nm}$.

\section{RESULTS AND DISCUSSION}

\subsection{Measurement, restoration and editing of colors}

Colors are measured of the embroidered elements of folk costume. Determined are 7 basic colors. Table 1 indicates the values of the color components from four color models RGB, Lab, HSV and CMYK, measured with a colorimeter. Have been selected such color models that are used for presentation of palettes and are suitable for color restoration.

Table 1. Colors in the Bulgarian national costume measured with colorimeter

\begin{tabular}{|c|c|c|c|c|c|c|c|c|c|c|c|c|c|c|}
\hline $\begin{array}{l}\text { Name } \\
\text { of } \\
\text { the } \\
\text { color }\end{array}$ & $\begin{array}{c}\text { General } \\
\text { view }\end{array}$ & $\mathbf{R}$ & G & B & $\mathbf{L}$ & a & b & $\mathbf{H}$ & $\mathbf{S}$ & V & C & M & $Y$ & $\mathrm{~K}$ \\
\hline red & & 174 & 31 & 37 & 38,040 & 55,670 & 34,580 & 357 & 82,200 & 68,200 & 0 & 0,822 & 0,787 & 0,318 \\
\hline green & & 26 & 125 & 54 & 45,840 & $-43,630$ & 30,640 & 137 & 79,200 & 49,000 & 0,792 & 0 & 0,568 & 0,510 \\
\hline black & & 24 & 24 & 24 & 8,250 & 0,001 & $-0,002$ & 0 & 0 & 9,400 & 0 & 0 & 0 & 0,906 \\
\hline yellow & & 212 & 183 & 29 & 74,795 & $\begin{array}{l}-3,672 \\
\end{array}$ & 72,488 & 50 & 86,300 & 83,100 & 0 & 0,137 & 0,863 & 0,169 \\
\hline white & & 255 & 248 & 244 & 98,004 & 1,650 & 2,733 & 22 & 4,300 & 100 & 0 & 0,028 & 0,043 & 0 \\
\hline purple & & 99 & 40 & 34 & 24,594 & 26,224 & 17,096 & 6 & 65,700 & 38,800 & 0 & 0,596 & 0,657 & 0,612 \\
\hline blue & & 52 & 54 & 105 & 24,916 & $\begin{array}{l}14,482 \\
\end{array}$ & $\begin{array}{l}-30,240 \\
\end{array}$ & 238 & 50,500 & 41,200 & 0,505 & 0,486 & 0 & 0,588 \\
\hline
\end{tabular}




\section{IR'TIE}

Ipplied Reseertrches in Technics, Technologies and Bducation Journal of the Faculty of Technics and Technologies, Trakia University https://sites.google.com/a/trakia-uni.bg/artte/

Table 2. Recovery algorithm for color of embroidered elements

\begin{tabular}{|c|c|c|}
\hline Stage & Operation & Description \\
\hline A & Loading of the image & The image is loaded in the Mtalab Workspace \\
\hline B & Reduction of the colors & $\begin{array}{l}\text { The colors in image I are reduced to numcolors, depending on } \\
\text { their number in the element. A function for image indexing } \\
\text { rgb2ind is used. } \\
\text { [x,map]= rgb2ind(I,numcolors,'nodither') }\end{array}$ \\
\hline $\mathrm{C}$ & Image filtering & Filter of type Disk is used \\
\hline D & $\begin{array}{l}\text { Defining a matrix of the } \\
\text { basic colors }\end{array}$ & $\begin{array}{l}\text { Defined is a matrix } m \text { having basic colors and its values are } \\
\text { normalized in the range }[0,1] \\
m=[1743137 ; 212554 ; 242424 ; 21218329 ; 255248244 ; \\
994034 ; 5254105] \\
m 1=m / 255\end{array}$ \\
\hline $\mathrm{E}$ & $\begin{array}{l}\text { Restoring of color in the } \\
\text { image of embroidered } \\
\text { elements }\end{array}$ & $\begin{array}{l}\text { Two nested loops are used and in the indexed image } x \text { colors } \\
\text { for each pixel are replaced with those defined in the matrix } m \text {, } \\
\text { each color is replaced with that of row from the matrix } R_{x} \\
\text { for } i=1: \text { length }(x(:, 1)) ; \text { for } j=1: \text { length }(x(1,:)) ; \text { if; } \quad x(i, j)==0 \text {; } \\
c(i, j, 1: 3)=m 1\left(R_{x},:\right) ; \text { end;end; end }\end{array}$ \\
\hline $\mathrm{F}$ & Visualization of the results & The results are visualized with a function Figure \\
\hline G & Saving the results in files & $\begin{array}{l}\text { The resulting image is saved in raster format }{ }^{*} . \mathrm{bmp},{ }^{*} \text {.mat and } \\
\text { as a spreadsheet }{ }^{*} \text {.xls }\end{array}$ \\
\hline
\end{tabular}

In Figure 5 are presented the colors of embroidered elements in a four-color wheel (Lab color wheel). There are both cognate and contrasting colors. The algorithm presented in [25] is used to obtain the colors of images. The work of the algorithm of color representation is visualized on the figure. The original image and this reduced to seven colors. The rectangles filled with the resultant colors are numbered. This numbering is used to indicate the RGB values in the range $0 \div 255$ for each color component.

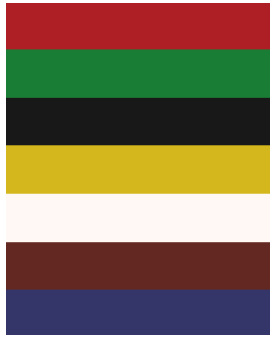

a) original image

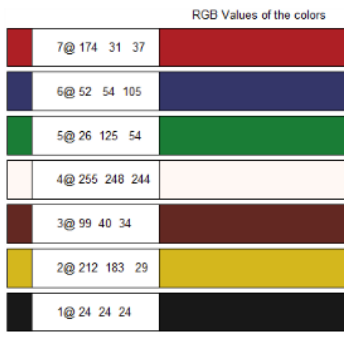

b) RGB values of the colors

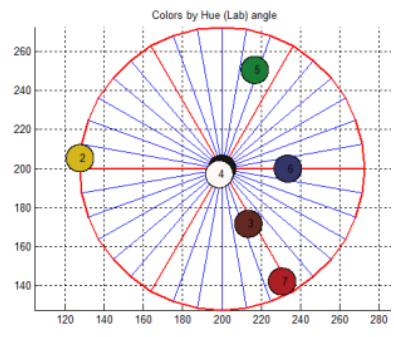

c) colors in Lab color wheel

Figure 5. Colors of the Bulgarian national costume

In capturing embroidered elements with document camera on the quality of the received digital color image influence many factors such as lighting, location of the object under the camera. This requires developing an algorithm for color restoration as embroidered items are of the same color in their separate areas, no matter what distortions in the resulting images.

An algorithm is developed for semi-automatic processing of embroidered elements of folk costume which works in the order presented in Table 2.

Figure 6 is an example of the work of the developed algorithm in color restoration of element A1. The background color in the image is red of the apron from the costume. The element consists of three basic colors - green, black and yellow, which are set in the algorithm for processing.

IRTTE Vol. 4, No. 2, 2016 ISSN 1314-8788 (print), ISSN 1314-8796 (online), doi: 10.15547/artte.2016.02.003 


\section{ARTIIE}

Ipplied Reseirlches in Technicis, Technologies and Bductition Journal of the Faculty of Technics and Technologies, Trakia University https://sites.google.com/a/trakia-uni.bg/artte/

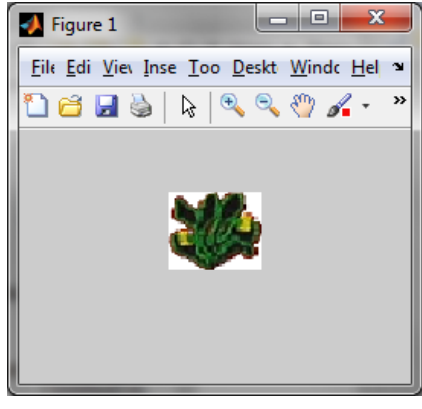

a) Original image

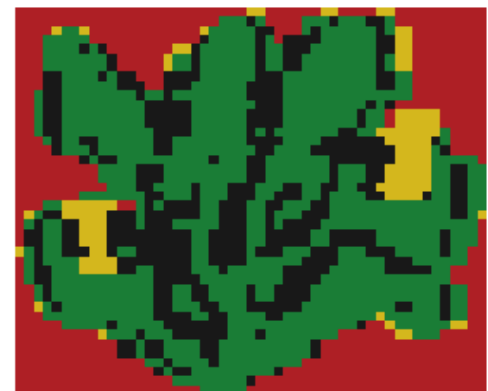

b) adapted to 4 basic colors

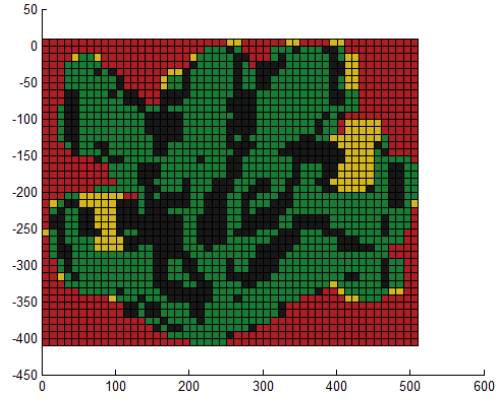

c) Final image

Figure 6. Stages of the algorithm for color restoration

An important stage of identification and recovery of embroidered members is identifying and removing errors in the process. For this purpose has been used algorithm proposed by Zhou et al [24]. The authors propose an algorithm that has simplified procedures, but with high efficiency, which solves four major problems for recognition. Extract object, identifies its location and detects and removes bad recognized pixels, defines relationships between color elements in the image. The advantage of using this algorithm is that it is not necessary to be preset information on the elements of the image the obtained results are with small error values.

The studied embroidered elements of the folk costume are processed with this algorithm. In Figure 7 are presented results from processing element $A 1$. There has been a reduction in the false recognized colors. Presented are the ratios of the colors of the element. In all processed embroidered elements of the folk costume are seen small error values $1-3 \%$.

For practical perspective, the use of the algorithm for detection and correction of decorative elements and embroidery, it can be noted the remark of the authors of the algorithm that for more complex objects is required enhancement of the algorithm, as if in a certain row in the image there are many pixels identified with wrong color in the processing, the next rows will start accumulating error.
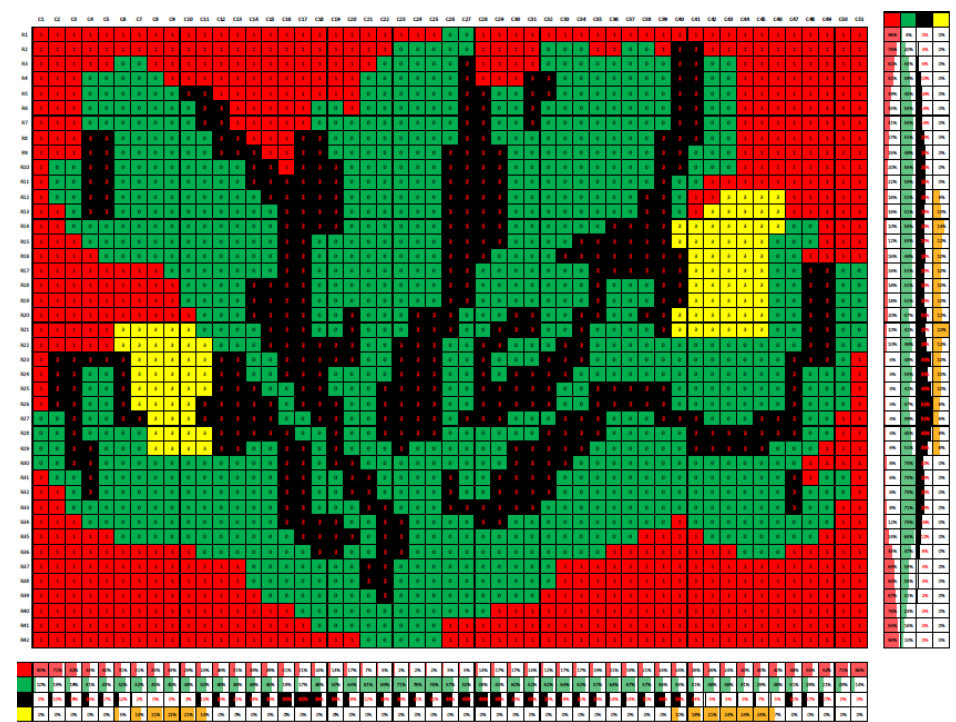

Figure 7. Ratios of the colors in embroidered element of folk costume

IRTTE Vol. 4, No. 2, 2016 ISSN 1314-8788 (print), ISSN 1314-8796 (online), doi: 10.15547/artte.2016.02.003 


\section{IRTTIE}

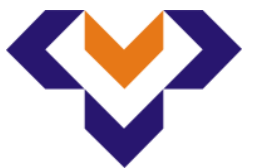

Ipplied Reseirlches in Technicis, Technologies and Bductition

Journal of the Faculty of Technics and Technologies, Trakia University https://sites.google.com/a/trakia-uni.bg/artte/

\subsection{Skeletonization of the elements}

In the literature $[17,18]$ is specifies that a convenient way of presenting objects in images for automated embroidery design is by morphological operation for skeletonization. The resulting skeletons can be used to generate a control file for embroidering machine. The advantage of using the skeleton of objects is that the topology and shape of element are remained, the resulting description is resistant to noise and distortion from capturing of the object image. The object can be restored from the skeleton.

In order to obtain the skeleton of the studied elements of folk costume were used morphological operations available in the software system Matlab. Operation is used skel. The general form of the function to obtain skeleton is: bwmorph ( $I_{B W}$, 'skel',n); where $I_{B W}-$ input image. It must be from class Logical or binary, it is two-dimensional and consists of a single element; $n$ - number of iterations of operation skel. If $n=\operatorname{lnf}$ operation is repeated until the image is not changed.
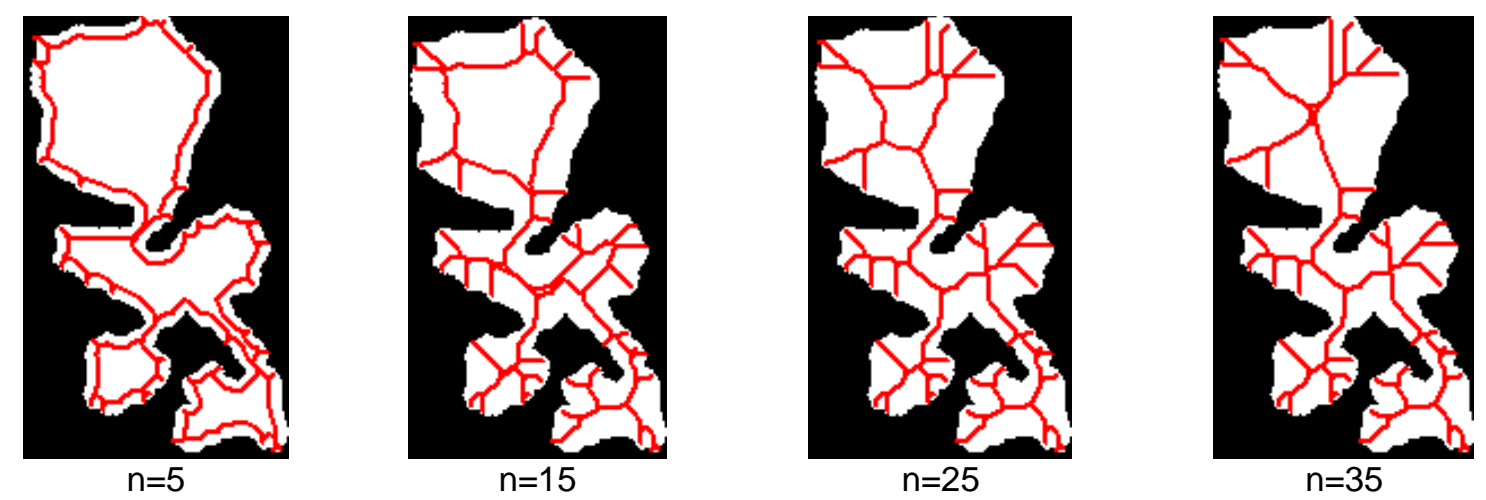

Figure 8. Effect of $n$ on the formation of the skeleton of the object in the image

The effect is studied of the coefficient $n$ on getting skeleton of embroidered elements of folk costume. In Figure 8 is an example to obtain the skeleton of an element depending on the value of this coefficient. Experimentally it has been found that to obtain the skeleton of the test objects the maximum number of required iterations of operation skel is $n=36$. The processing time is within 4,36-4,52s depending on the image resolution and the size of the element.

In addition to storing information for the element and generate control files for embroidery machine the skeletons can be used to restore the image of the object [19].
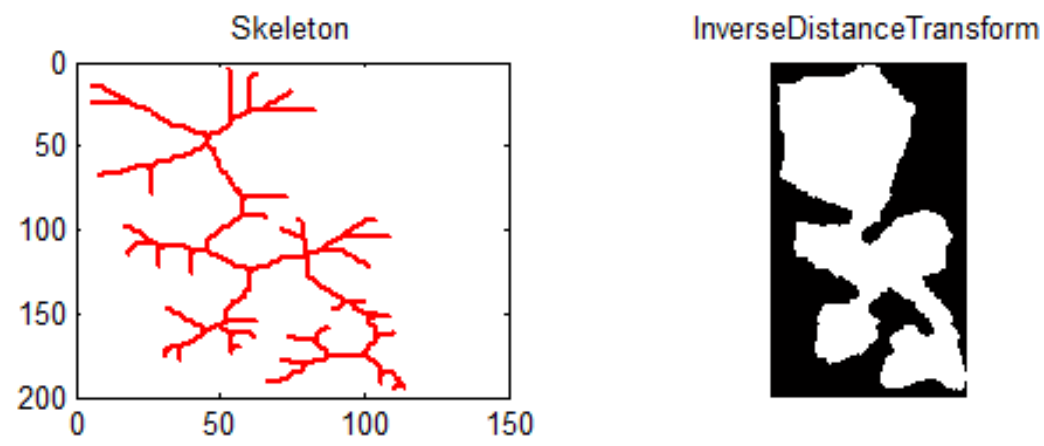

Figure 9. Restoration of element from skeleton

IRTTIE Vol. 4, No. 2, 2016 ISSN 1314-8788 (print), ISSN 1314-8796 (online), doi: 10.15547/artte.2016.02.003 


\section{ARTILE \\ $Y^{2}$ \\ Ipplied Reseirlches in Technicis, Technologies and Bductition \\ Journal of the Faculty of Technics and Technologies, Trakia University https://sites.google.com/a/trakia-uni.bg/artte/}

The information received and stored by the skeleton of the element is not sufficient for its restoration. The restoration of element can be realized by inverse distance transformation. In Matlab programming environment this operation is realized by function poly2mask.

In Figure 9 is an example of restoration of an element from its skeleton by function inverse distance transformation. The algorithm for realizing this transformation is slower compared to that for preparing the skeleton. The recovery time of the object is $7,8-8,5 \mathrm{~s}$ depending on the skeleton of the processed element of the folk costume.

\subsection{Generation of files for embroidery machines}

The results of the work are checked by software for the embroidery design to visualize the final effect. In most cases, satisfactory results were obtained. Used software products are SewArt and my editor ${ }^{\mathrm{TM}}$.

SewArt is software for converting raster images to files for embroidery machines. Therefore the software belongs to the systems automatic digitization. The work with software requires prior acquaintance with its workspace and toolbars. Most important operations of conversion are displayed as buttons. To generate quality file for Embroidery is necessary the image to be with areas with homogeneous colors. For this purpose in the program are provided functions for image processing.

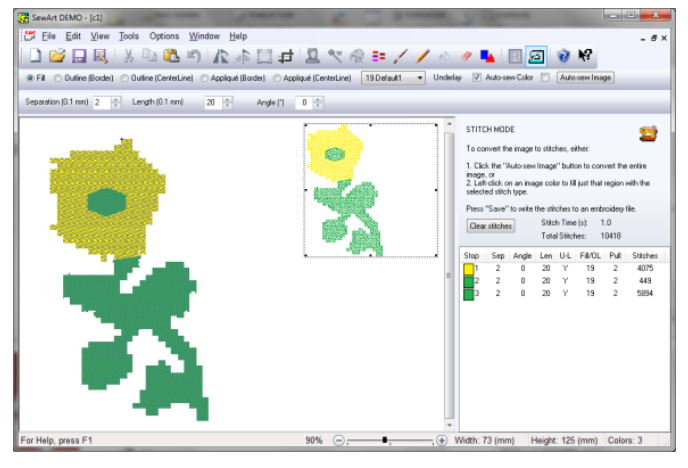

a) generation of embroidery file

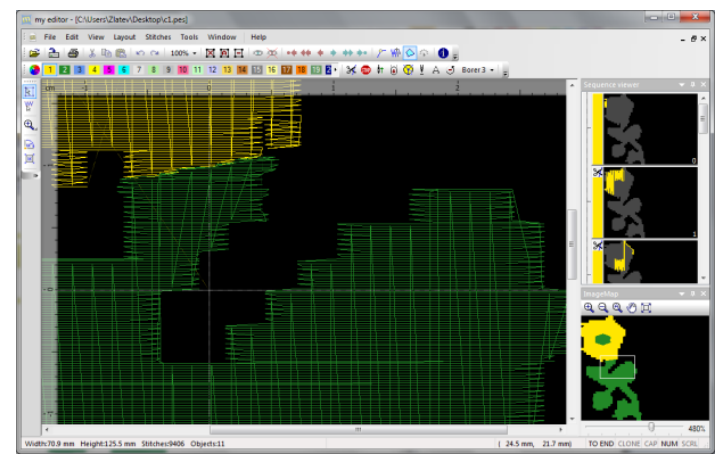

b) editing of embroidery file

Figure 10. Generating and Editing control file for embroidery machine

my editor ${ }^{\mathrm{TM}}$ is software for visualization and editing files for embroidery machines. Its main function is editing and converting files that can be used with machines from different manufacturers. The editing involves adding / removing single or multiple stitches.

The presented software used for image processing for the embroidered elements of folk costume are used to generate files *.pes for embroidery machines Brother (Figure 10). Through the program for editing these files can easily be converted to such machines from other manufacturers.

\subsection{Digital collection of embroidery elements from Bulgarian folk costume}

The data for the embroidery elements from Bulgarian national costume, raster and vector files were used in constructing of a digital collection that is published in created for this purpose Internet site. The first important step in the development of the website is the choice of platform. The main advantage of an online website builder platform is that it is quick and easy to use, and often does not require prior experience. Often, a website can be built and

IRITIE Vol. 4, No. 2, 2016 ISSN 1314-8788 (print), ISSN 1314-8796 (online), doi: 10.15547/artte.2016.02.003 


\section{ART'TE \\ $Y$ \\ Ipplied Reseirlches in Technicis, Technologies and Bductition \\ Journal of the Faculty of Technics and Technologies, Trakia University https://sites.google.com/a/trakia-uni.bg/artte/}

be up and running live on the Internet. In creation of the website for the digital collection are used the results of existing websites on this theme. It is considered how are organized these sites, their realization, how these sites are complete, how is presented the information. The need for current study arose in order to outline the proper model for development and to explore what the user intuitively expects to see in this type websites.

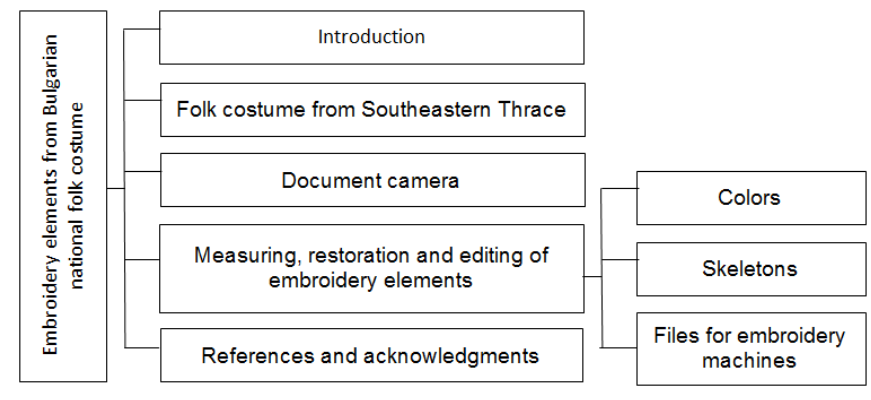

a) Structure of the site

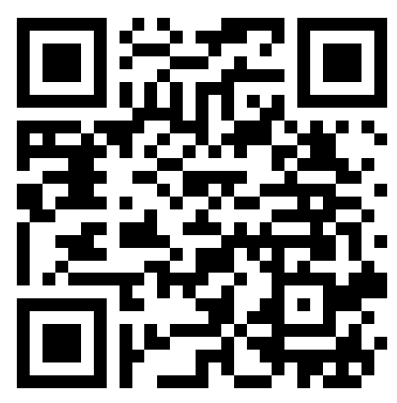

b) QR code of the site

Figure 11. Website with data for the embroidered elements

For quick and easy access to the digital collection of embroidery elements and in its website is generated QR code (Figure 11). Having a website and using QR code with it can place a positive first impression of the user's mind.

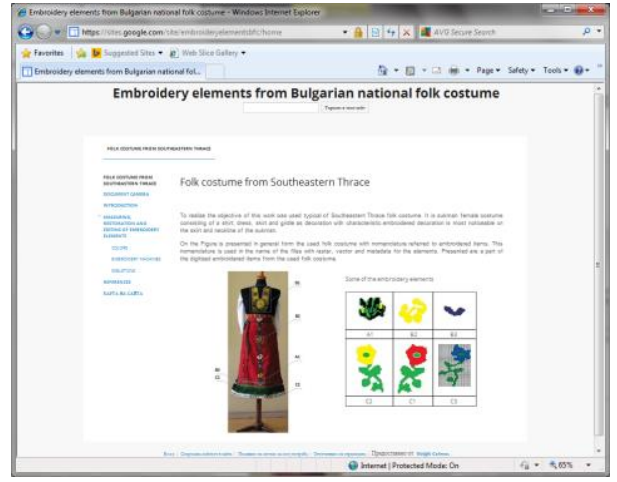

a) Main page

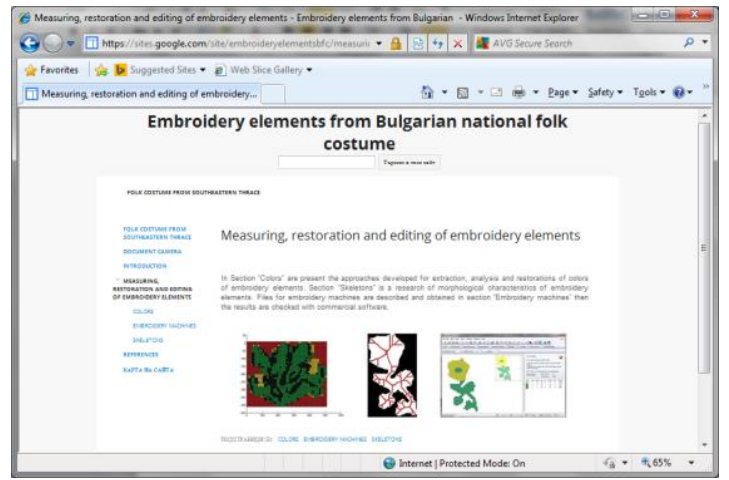

b) Organization of the study

Figure 12. Website with data for the embroidered elements

This website presents the main results of the work. In this way it will be available to many people who have a connection to the Internet via mobile phones, tablets, personal and mobile computers, televisions and other „smart“ devices.

In the main page (Figure 12a) of the site is presentation of the used Bulgarian folk costume and some of the embroidered elements. On the next sub-page (Figure 12b) is presented the organization of entire work. A brief description is made of these figures. All of the embroideries can be viewed and downloaded in *.PDF, *.DXF, * .XLS, *.PES, *.BMP, *.MAT file formats. This way of presenting the geometries and design of their base embroidery elements was used in all pages of the site. 


\section{ARTTIE $Y$}

Ipplied Reseirlches in Technicis, Technologies and Bductition Journal of the Faculty of Technics and Technologies, Trakia University https://sites.google.com/a/trakia-uni.bg/artte/

\section{CONCLUSION}

This research is an analysis of two dimensional images of embroidery elements and the development of techniques for shape and color segmentation in the automation of embroidery designs. These analyses are made over embroidery elements of Bulgarian folk costume.

In the studies relating to the recognition of embroidered elements and automation of processes for manufacturing such products are used complex computational procedures and expensive equipment and should be sought simpler procedures and more common technical devices having the similar opportunities for image processing. For this reason it is selected a document camera, which can be used both for learning and research and is commonly used technical device in the universities.

For ease of use of embroidery elements on clothing to create patterns, decoration of clothes, are applied analytical techniques and image processing. The values of color components for the embroidery elements are obtained in four commonly used in the practice color models. An algorithm is developed for semi-automatic color restoration of embroidered elements of folk costume that solves the problem with distortions in the raw images. Necessary number of iterations and the maximum processing time is established in obtaining of skeletons of the embroidery elements. It is presented a way for restoration of elements from their skeletons. These make embroidery elements resistant to noise and distortion from capturing of the object image. The results of the work are checked by software for the embroidery design to visualize the final effect. Through the software tools for editing the obtained files can easily be converted to embroidery machines from different manufacturers.

The main results of the work are organized in digital collection that is published in website, which provides more people to access them and facilitate their use in the practice.

\section{ACKNOWLEDGMENTS}

We thank Galya Dolapchieva for provided Bulgarian folk costume from Southeastern Thrace.

\section{REFERENCES}

[1] Diao H., G. Yan, Integral design scheme of computerised embroidery machine's control system, Journal of Engineering Design, 10(4), 2003, pp.188-190.

[2] Dineva P., Z. Kazlacheva, Design of women wear with three-dimensional elements, XXIV International scientific conference "Management and quality" for young scientists, 2015, ISSN: 1314-4669.

[3] Georgiev G., N. Georgieva, Investigation possibilities for the use of free software for data processing used for accurate measurement details through photogrammetry, ARTTE Vol. 2, No. 3, 2014, ISSN 1314-8796, pp. 202-210.

[4] Georgiev G., Z. Zlatev, Comparative analysis for measuring the geometry machine parts, Proceedings of ICTTE 2013, ISSN 1314-9474, pp.49-56.

[5] Georgieva K., E. Kirilova, Ts. Georgieva, P. Daskalov, Selection of informative color features complexes from digital images of healthy and diseased vine leaves, ARTTE Vol. 3, No. 4, 2015, ISSN 1314-8796, pp.289-295.

[6] llieva J., Fashion design using decorative bands based on the golden and Fibonacci forms, ARTTE, Vol.3, No.3, 2015, ISSN 1314-8796, pp.265-274.

[7] Kazlacheva Z., J. Ilieva, History of the costume and fashion, 2014, ISDN 978-954-338101-2.

IRTTIE Vol. 4, No. 2, 2016 ISSN 1314-8788 (print), ISSN 1314-8796 (online), doi: 10.15547/artte.2016.02.003 
[8] Kuo C.F.J., C.T.M. Hsu, C.Y. Shih, Automatic Pattern Recognition and Color Separation of Embroidery Fabrics, Textile Research Journal, Vol.81, 2011, pp.1145-1157.

[9] Kuo C.F.J., B.L. Jian, H.C. Wu, K.C. Peng, Automatic machine embroidery image color analysis system. Part I: Using Gustafson-Kessel clustering algorithm in embroidery fabric color separation, Textile Research Journal, April 2012, Vol.82, No.6, pp.571-583.

[10] Kuo C.F.J., B.L Jian, C.P. Tung, H.C. Wu, Automatic Machine Embroidery Image Color Analysis System, Part II: Application of the Genetic Algorithm in Search of a Repetitive Pattern Image, Textile Research Journal, Vol.82, 2012, pp.1099-1106.

[11] Kuo C.F.J., C.Y. Kao, B.L. Jian, C.P. Tung, Automatic machine embroidery image color analysis system, part III: Integration of machine embroidery image color analysis system, Textile Research Journal, December 2012, Vol.82, No.20, pp.2090-2098.

[12] Kuo C.F.J., Y. Juang, A study on the recognition and classification of embroidered textile defects in manufacturing, Textile Research Journal, March 2016, Vol.86, No.4, pp.393-408.

[13] Li H., W. Liu, X. Li, Construction of Basic-Element Database for Traditional Chinese Culture in Industrial Design, ITQM 2016, Procedia Computer Science, vol.91, 2016, pp.1011-1017.

[14] Li J., Research on Vectorization of Embroidery Images Consisting of Straight Lines \& Circular Arcs, Modern Applied Science, Vol. 3, No.6, 2009, pp.141-144.

[15] Mladenov M., S. Penchev, M. Deyanov, Complex assessment of food products quality using analysis of visual images, spectrophotometric and hyperspectral characteristics. International Journal of Engineering and Innovative Technology (IJEIT), Vol. 4, Iss. 12, June 2015, ISSN: 2277-3754, pp.23-32.

[16] Mo H., B. Xu, W. Ouyang, J. Wang, Color segmentation of multi-colored fabrics using selforganizing-map based clustering algorithm, Textile Research Journal, February 152016.

[17] Montero A. S., Efficient Feature Extraction for Shape Analysis, Object Detection and Tracking, PhD Thesis, Ottawa, Canada, 2016.

[18] Rocha A. L. P., Segmentation and Line Filling of 2D Shapes, Thesis for degree in Electrical and Computer Engineering, Ottawa, Canada, 2013.

[19] StackOverflow, http://stackoverflow.com/questions/7648186/is-there-any-functionopposite-to-bwmorphimage-skel-in-matlab-or-c-c-code (available on 17.08.2016).

[20] Shih C.Y., C.F.J. Kuo, J.H. Cheng, A study of automated color, shape and texture analysis of Tatami embroidery fabrics, Textile Research Journal, October 132015.

[21] Tasev G., K. Krastev, Exploration of mathematical model for optimization of frequency of diagnosis of the elements of machines, Proceedings of The 11th International Conference, Reliability and statistics in transportation and communication, Latvia, 2011, ISBN 978-9984-818-34-4, pp.115-119.

[22] Zhang R., B. Xin, A review of woven fabric pattern recognition based on image processing technology, Research Journal of Textile and Apparel, Vol.20 Iss.1, 2016, pp.37-47.

[23] Zheng D., A new method for automatic separation of fabric color, Textile Research Journal September 2015, Vol.85, No.14, pp.1520-1538.

[24] Zhou D., L. Zhou, X. Sheng, J. Sun, A Novel Weave/Color Repeat Extraction Method with Error Tolerance, Journal of Engineered Fibers and Fabrics, http://www.jeffjournal.org, Vol.9, Iss.2, 2014, pp.127-139.

[25] Zlatev Z., J. Ilieva, Design of textile patterns by using colors from the Bulgarian national costumes, ARTTE Vol. 3, No. 4, 2015, ISSN 1314-8796, pp.309-316. 